\title{
PENERAPAN PEMBELAJARAN MAKE A MATCH TERHADAP HASIL BELAJAR SISWA PADA POKOK BAHASAN PERUBAHAN MATERI KELAS VII SMP
}

\author{
Bronika Septiani Sianturi \\ Surel: bronikaseptiani@yahoo.com
}

\begin{abstract}
This study aims to improve student learning outcomes by using the make a match learning model on the subject of changes in class VII material in Sibabangun 2 Public Middle School. This type of research is a quasiexperimental study with two groups pre-test and post-test research designs. The population of this study was all class VII students, amounting to three classes. From the data analysis for the experimental class, pre-tests $(46.50 \pm$ $8.53)$ and post-tests $(81.5 \pm 7.85)$ were obtained. In the control class, pretests $(32.7 \pm 9.54)$ and post-tests were obtained $(64.2 \pm 11.41)$. Both data are normally distributed. The results of testing hypotheses using the oneparty $t$ test at $=0.05$ and $d k=48$ obtained tcount $>$ ttable or $4.513>2.154$ then Ha is accepted, Improving student learning outcomes after being given treatment of the make a match learning model is better than conventional learning on the subject discussion of Material Changes.
\end{abstract}

Keywords: Make a Match, Learning Outcomes, Learning

\begin{abstract}
ABSTRAK
Penelitian ini bertujuan untuk meningkatkan hasil belajar siswa dengan menggunakan model pembelajaran make a match pada pokok bahasan perubahan materi kelas VII di SMP Negeri 2 Sibabangun. Jenis penelitian ini adalah penelitian quasi eksperimen dengan desain penelitian two group pre-tes dan pos-tes. Populasi penelitian ini adalah seluruh siswa kelas VII yang berjumlah tiga kelas. Dari analisa data untuk kelas eksperimen diperoleh pre-tes $(46,50 \pm 8,53)$ dan pos-tes $(81,5 \pm 7,85)$. Pada kelas kontrol diperoleh pre-tes $(32,7 \pm 9,54)$ dan pos-tes $(64,2 \pm 11,41)$. Kedua data tersebut berdistribusi normal. Hasil pengujian hipotesis dengan menggunakan uji t satu pihak pada $\alpha$ $=0,05$ dan $\mathrm{dk}=48$ diperoleh $\mathrm{t}_{\text {hitung }}>\mathrm{t}_{\text {tabel }}$ atau 4,513 $>2,154$ maka Ha diterima, Peningkatan hasil belajar siswa setelah diberikan perlakuan model pembelajaran make a match lebih baik dibandingkan dengan pembelajaran konvensional pada pokok bahasan Perubahan Materi.
\end{abstract}

Kata Kunci: Make a Match, Hasil Belajar, Pembelajaran

\section{PENDAHULUAN}

Kimia merupakan ilmu yang termasuk rumpun IPA, oleh karenanya kimia mempunyai karateristik sama dengan IPA. Ilmu kimia merupakan pengetahuan yang berupa fakta, teori, hukum temuan sains dan proses kerja ilmiah.
Walaupun demikian kimia bukan hal asing dalam kehidupan karena hampir semua aspek kehidupan berhubungan dengan ilmu kimia atau hasil penerapan ilmu kimia. Hal ini membuktikan bahwa siswa sebenarnya telah memiliki pengetahuan tentang ilmu kimia 
tetapi seringkali tidak mereka sadari sehingga ilmu kimia tidak begitu diminati siswa karena kurangnya penerapan ilmu kimia dalam kehidupan siswa.

Berdasarkan hasil observasi maupun melalui beberapa hasil penelitian, pada umumnya siswa berpendapat bahwa kimia itu sulit untuk dipahami, pandangan para siswa terhadap mata pelajaran kimia sebagai pelajaran yang sulit untuk di mengerti dan sangat membosankan. Salah satu faktor penyebab rendahnya hasil belajar siswa saat ini adalah berkaitan dengan strategi pembelajaran yang masih konvensional, dimana guru terlalu mendominasi peserta didik sehingga keterlibatan peserta didik dalam proses pengajaran sangat kurang. Guru cenderung hanya memberikan atau memindahkan informasi sebanyak-banyaknya kepada siswa sehingga konsep dan aturan dalam pelajaran tersebut terkesan saling terisolasi dan tidak bermakna.

Tugas guru, di kelas tidak hanya menyampaikan informasi kepada siswa, tetapi harus menjadi fasilitator yang bertugas memberikan kemudahan belajar kepada seluruh siswa agar mereka dapat belajar dalam suasana yang menyenangkan, gembira semangat sehingga dalam diri siswa akan tumbuh motivasi dan minat untuk belajar kimia sehingga hasil belajar kimia siswa dapat lebih meningkat. Salah satunya metode pembelajaran yang tepat dan bagus ditetapkan untuk menciptakan suasana belajar yang menyenangkan seperti ini adalah Model Pembelajaran Make A Match.

Model pembelajaran make a match sangat menarik untuk dipraktekkan dalam pembelajaran IPA karena memiliki kelebihan yaitu 1) guru dapat menciptakan suasana belajar aktif dan menyenangkan karena seluruh siswa aktif dalam melakukan tugasnya. 2) dapat meningkatkan hasil belajar siswa. 3) menjalin kerja yang dinamis antara siswa dengan siswa dan siswa dengan guru.

Adapun tujuan dalam penelitian ini adalah untuk untuk mengetahui: Apakah hasil belajar siswa lebih baik dengan penerapan pembelajaran Make A Match dibandingkan dengan pembelajaran konvensional pada pokok bahasan Perubahan Materi Kelas VII SMP Negeri 2 Sibabangun Tahun Ajaran 2018/2019.

\section{METODE PENELITIAN}

Penelitian ini dilaksanakan di SMP Negeri 2 Sibabangun Kabupaten Tapanuli Tengah pada bulan Juni-Agustus 2018. Dalam penelitian ini yang menjadi populasi adalah seluruh kelas VII yang berjumlah 3 kelas di SMP Negeri 2 Sibabangun Tahun Pelajaran 2018/2019. Sampel dalam penelitian ini ada dua kelas yaitu kelas eksperimen dan kelas kontrol. Penentuan kelas dipilih dengan menggunakan teknik pengambilan sampel secara acak. Kelas eksperimen menggunakan pembelajaran make a match dan 
Bronika Septiani : Penerapan Pembelajaran Make...

kelas kontrol menggunakan pembelajaran Konvensional.

Sampel yang diambil dalam penelitian ini dikelompokkan dalam dua kelompok yaitu kelompok pertama sebagai kelas eksperimen dan kelompok kedua sebagai kelas kontrol. Pada kelas eksperimen diberikan perlakakuan khusus dengan cara memberikan penerapan penggajaran make a match. Sedangkan kelas kontrol tidak diberi pengajaran melainkan dengan cara konvensional.

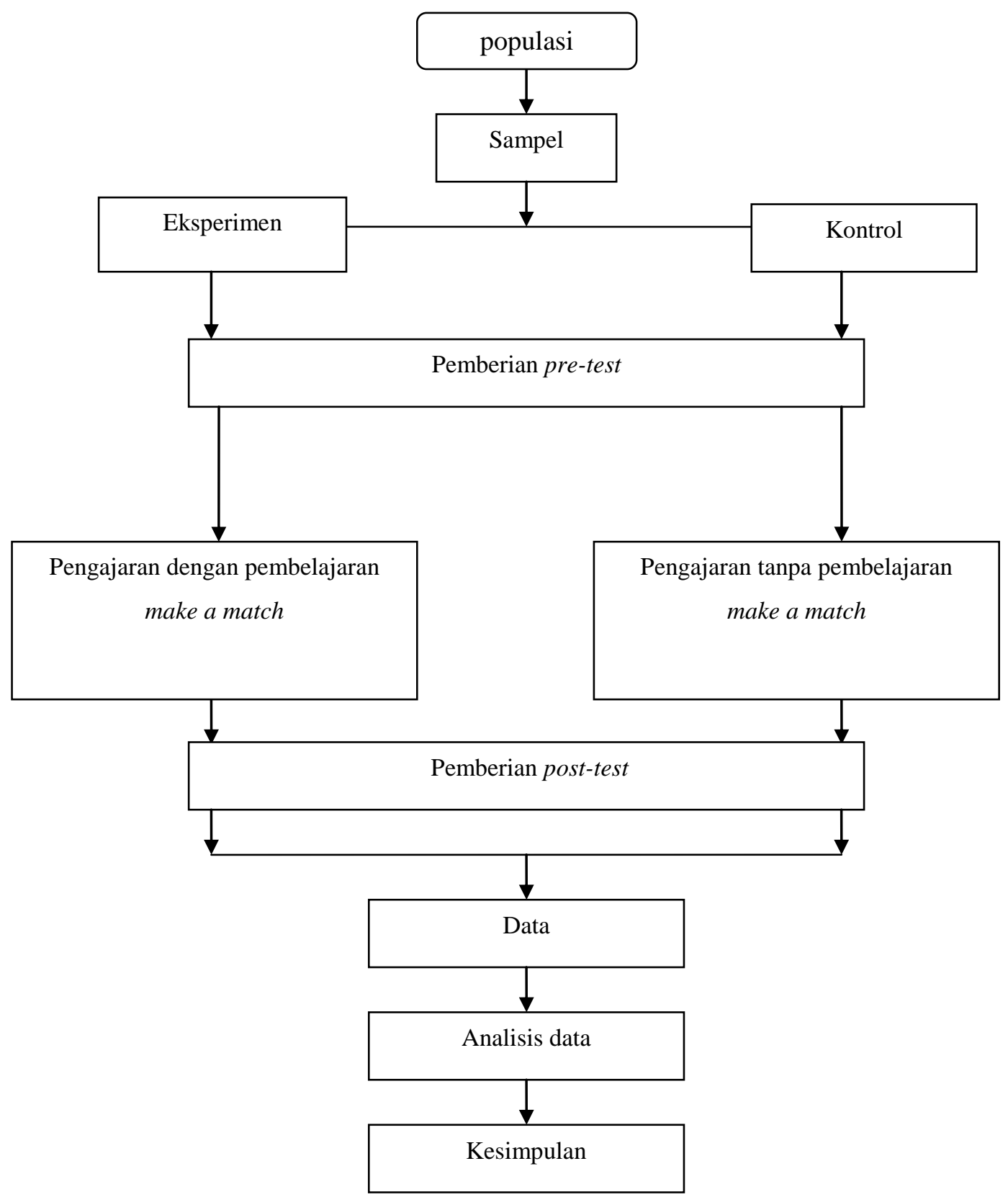

Gambar 1. Pelaksanaan Penelitian 

Instrumen yang digunakan untuk mengumpulkan data hasil belajar siswa adalah tes hasil belajar pada sub materi pokok perubahan materi. Tes ini berbentuk pilihan berganda yang berjumlah 30 soal dengan 4 option pilihan. Tes yang baik adalah tes yang valid dan reabilitas, untuk mengetahui validitas tes digunakan validitas isi dan validitas ramalan.

Data skor pretes sebelum perlakuan diperoleh dengan memanfaatkan jawaban siswa sekaligus untuk mengidentifikasikan tingkat pemahaman sebelum mengikuti kegiatan belajar.

Peningkatan hasil belajar siswa yang diajarkan dengan menggunakan pembelajaran make a match dapat dilihat dengan menggunaka persamaan Gain (Pencapaian) persamaan:

$$
g=\frac{\text { skorpostes }- \text { skorpretest }}{\text { skormaksimum }- \text { skorpretest }}
$$

Dengan Kriteria g (gain)

$$
\begin{array}{ll}
\mathrm{g}<0,3 & =\text { rendah } \\
0,3<\mathrm{g}<0,7 & =\text { sedang } \\
\mathrm{g}>0,7 & =\text { tinggi }
\end{array}
$$

\section{HASIL PENELITIAN DAN PEMBAHASAN}

Perhitungan untuk uji normalitas kedua kelas dapat dilihat perhitungannya pada tabel.

Tabel 1. Uji Normalitas Data Hasil Belajar Kimia Siswa Untuk Kelas Kontrol

\begin{tabular}{c|c|c|c|c}
\hline \multirow{2}{*}{ No } & \multirow{2}{*}{ Data } & \multicolumn{2}{|c|}{ Data } & \multirow{2}{*}{ Keterangan } \\
\cline { 3 - 4 } & & $\mathrm{L}_{\text {hitung }}$ & $\mathrm{L}_{\text {tabel }}$ & \\
\hline 1 & Pre-test & 0,1604 & 0,173 & Normal \\
\hline 2 & Post-test & 0,1622 & 0,173 & Normal \\
\hline
\end{tabular}

Tabel 2. Uji Normalitas Data Hasil Belajar Kimia Siswa untuk Kelas Eksperimen

\begin{tabular}{c|c|c|c|c}
\hline \multirow{2}{*}{ No } & \multirow{2}{*}{ Data } & \multicolumn{2}{|c|}{ Data } & \multirow{2}{*}{ Keterangan } \\
\cline { 3 - 4 } & & $\mathrm{L}_{\text {hitung }}$ & $\mathrm{L}_{\text {tabel }}$ & \\
\hline 1 & Pre-test & 0,1426 & 0,173 & Normal \\
\hline 2 & Post-test & 0,1365 & 0,173 & Normal \\
\hline
\end{tabular}

Setelah diketahui bahwa kedua sampel penelitian berdistribusi normal dan mempunyai varians yang sama atau homogen, dengan demikian hipotesis dapat dilakukan dengan uji t diperoleh harga t yaitu: $t_{\text {hitung }} \quad$ : 4,513. Kemudian dibandingkan dengan harga $t_{\text {tabel }}$ pada $\mathrm{dk}=48$ dan taraf $\alpha=0,05$. Harga $\mathrm{t}_{\text {tabel }}$ pada $\mathrm{dk}=48$ dengan taraf nyata $\alpha=0,05=4,513$ (dengan interpolasi).

Dengan kriteria pengujian adalah : Ha diterima apabila harga $t_{\text {hitung }}(4,513)>t_{\text {tabel }}(2,154)$. Dengan kata lain, peningkatan hasil belajar kimia siswa setelah diberikan perlakuan penerapan pembelajaran make a match lebih baik 
dibandingkan dengan pembelajaran Konvensional.

Setelah diketahui bagaimana kemampuan awal para siswa dilakukan pembelajaran yang berbeda. Pada akhir pembelajaran siswa diberikan pos-tes untuk mengetahui bagaimana hasil belajar kedua kelompok siswa setelah diberikan perlakuan. Hasil penelitian diperoleh rata-rata postes siswa yang diajarkan dengan model pembelajaran make a match (kelas eksperimen) adalah 81,5 sedangkan untuk kelas kontrol yang menggunakan model pembelajaran konvensional 64,2. Berdasarkan hasil ini dapat dilihat bahwa ada perbedaan yang signifikan hasil belajar (pos-tes) kedua kelompok siswa.

Selanjutnya sebelum dilakukan pengujian hipotesis untuk mengetahui ada tidaknya pengaruh model pembelajaran make a match dengan model pembelajaran konvensional, terlebih dahulu dilakukan uji prasyarat data. Hasil pengujian homogenitas dengan menggunakan uji F dapat disimpulkan bahwa data pre-tes siswa antara kelompok sampel tersebut dinyatakan dapat mewakili seluruh populasi yang ada. Sedangkan hasil pengujian normalitas data dengan menggunakan uji Lilliefors, diperoleh kesimpulan bahwa data pre-tes kedua kelompok sampel memiliki data normal. Dengan demikian syarat pengujian homogenitas dan normalitas data telah terpenuhi sehingga dapat dilanjutkan dengan pengujian hipotesis.

Pengujian hipotesis dilakukan dengan tujuan untuk mengetahui ada tidaknya pengaruh model pembelajaran make a match terhadap hasil belajar siswa pada pokok bahasan perubahan materi. Pengujian hipotesis untuk pos-tes dilakukan dengan uji t satu pihak, yaitu pihak kanan diperoleh $t_{\text {hitung }}=4,513$ dan harga $t_{\text {tabel }}=2,154$, maka $t_{\text {hitung }}>$ $t_{\text {tabel }}(4,513>2,154)$ maka Ha diterima artinya Peningkatan hasil belajar siswa setelah diberikan perlakuan model pembelajaran make a match lebih baik dibandingkan dengan pembelajaran konvensional pada pokok bahasan Perubahan Materi dengan $\%$ peningkatan hasil belajar siswa sebesar 74,53\%.

Dengan menggunakan model pembelajaran make a match hasil belajar siswa lebih baik, karena pada saat proses belajar mengajar siswa melakukan diskusi kelompok dan permainan serta tournament, siswa juga lebih termotivasi pada waktu pembelajaran dilaksanakan. Belajar dengan menggunakan pembelajaran make a match akan menumbuhkan rasa percaya diri dan jiwa sosial yang tinggi pada siswa karena siswa diberi kesempatan untuk mengembangkan aktifitas mandiri dan saling membantu dalam mempelajari konsep kimia ditambah lagi dengan penyajian yang menarik sehingga akan terbentuk proses belajar mengajar yang menarik didalam kelas. 
Waktu pelaksanaan pembelajaran make a match ada beberapa kesulitan yang dihadapi oleh peneliti dimana siswa cenderung ribut. Kelemahan lain juga terletak pada kondisi waktu. Model pembelajaran make a match membutuhkan waktu yang cukup banyak.

Ada pengaruh yang baik pada pembelajaran make a match pada kelompok yang hasil belajarnya tinggi pada kelas eksperiment sebesar $76,8 \%$. Dimana pada saat pembelajaran kelompok tinggi cenderung lebih termotivasi dalam waktu proses pembelajaran.

\section{SIMPULAN}

Setelah melakukan penelitian, perhitungan data, dan pengujian hipotesis, maka diperoleh beberapa kesimpulan antara lain sebagai berikut:

a. Ada perbedaan yang signifikan antara hasil belajar siswa yang diberi model pembelajaran make a match dengan model pembelajaran konvensional pada materi perubahan materi. Hal ini ditunjukkan oleh pengujian hipotesis di mana $t_{\text {hitung }}>\mathrm{t}$ tabel atau $4,513>2,154$ pada taraf signifikan $\alpha=0,05$ dengan $\mathrm{dk}=$ 48.

b. Peningkatan hasil belajar siswa setelah diberikan perlakuan model pembelajaran make a match lebih baik dibandingkan dengan pembelajaran konvensional pada pokok bahasan Perubahan Materi dengan $\%$ peningkatan hasil belajar siswa sebesar $74,53 \%$.

c. Peningkatan hasil belajar siswa setelah diberikan perlakuan model pembelajaran make a match lebih baik dibandingkan dengan pembelajaran konvensional pada pokok bahasan Perubahan Materi.

\section{DAFTAR RUJUKAN}

Dimyati, dkk. 2013. Belajar \& Pembelajaran. Jakarta: Rineka Cipta.

Djamarah, Syaiful Bahri. 2011. Psikologi Belajar. Jakarta: Rineka Cipta.

Hartono, Rudi. 2013. Ragam Model Mengajar Yang Mudah Diterima Murid. Jakarta: Diva Press.

Isjoni. 2009. Cooperatif Learning Efektifitas Pembelajaran Kelompok. Surabaya: Alfabeta.

Kamilati, N. 2006. Mengenal Kimia SMP Kelas VII. Jakarta: Yudhistira.

Muid. 2007. Inspirasi Sains Kimia Kelas VII. Jakarta: Ganeca Exact.

Slameto. 2010. Belajar dan FaktorFaktor yang Mempengaruhinya. Jakarta: Rineka Cipta.

Trianto, 2012. Mendesain Model Pembelajaran InovatifProgresif. Jakarta: Kencana Prenada Media Group. 